\title{
Wildlife in urban parks-why sustain it?
}

\author{
Maciej Luniak \\ (Museum and Institute of Zoology, Polish Academy of Sciences)
}

\begin{abstract}
The author argues that it is not possible, especially in an urbanized landscape, to trace any clear dividing lines between natural structures and processes and those caused by the human. Simplifying things to the extreme, we assume that "wildlife" includes those organisms which live permanently (or are capable of living) in a given area without any deliberate human assistance. Arguments for sustaining "wild life" in city parks are many, deriving from humanitarian, ecological, social, or economic considerations. The author acquaints the reader with research conducted as part of the project Nature of the Skaryszewski Park. The diagnosis relating to that Warsaw park enabled the formulation of a range of recommendations whose application would protect and foster living nature in city parks.
\end{abstract}

Key words:

natural environment, sustainability, urban landscape, wild life

\section{Nature and wildlife}

Put in simple terms, "nature" generally denotes a complex of relatively natural (in human-transformed conditions) elements of the ecosystem-a local arrangement of co-dependencies of the biotope (climate, hydrological profile, geology, soil, etc.) and living organisms ("microbes," fungi, plants, and animals), in other words the biocœnosis, including human influence. Recently, the term "wildlife" has seen increasing use. In simple terms it describes "animate nature," although various "microbes" in the biocœnosis are generally excluded from its scope, being treated rather as a component of the environment in which wildlife is found.

The universal canon of the functioning of animate nature, even the most depleted (e.g., in urban conditions), is the cycle and flow of matter and associated energy between three levels of livingelements of ecosystems-(1) producers of organic matter, (2) its consumers, and (3) decomposers: 
(1) Producers-plants (and algae), by means of photosynthesis (water $+\mathrm{CO}_{2}$ + other inorganic compounds + solar energy), create organic matter-that is, various types of plant tissue (e.g., foliage, wood, fruit). In part, said matter, in dead form (e.g., fallen leaves), transitions directlyto the level of decomposers (3), and partially toconsumers (2).

(2) Consumers-animals in the multi-tiered food chain (herbivores, predators, scavengers) process it into their own living tissue, feces, as well as partially contribute to fragmentation and decomposition. Dead organic matter from levels (1) and (2) passes to level (3)

(3) Decomposers-various groups of invertebrates, fungi, "microbes," living for the most part in the soil and its proximate horizons, which disintegrate and decompose it into mineral components. At this point the loop of matter circulation closes. In its mineralized form, it is yet again absorbed by plants (1), for which it constitutes an indispensable prerequisite of existence (unless it is replaced by fertilizer).

These are the fundamental principles according to which animate nature functions; respecting (or negating) them, for instance in urban greenery, is decisive for the sustenance or degradation of wildlife. In the arrangement and management of city parks, one generally notices (either eliminating or tolerating) the existence of wildlife components belonging to level (1) of the aforementioned cycle-in other words, the "wild" flora-since it is the most noticeable and fits in with traditional gardening practices. The consumers (2), or presence of "wild" animals, as well as the level of decomposers which "feed" plants (3)-mainly the abundant wildlife of the soil-are largely ignored despite being an important element in a park's ecosystem.

It is not possible, especially in an urbanized landscape, to trace clear dividing lines between natural structures and processes and human influence. Simplifying things substantially, we presume that "wildlife" consists of those organisms (most often entire populations or plant communities) which permanently-for many generations or seasons of their existence-endure (or are capable of living) in a given area without deliberate human assistance. Therefore, the introduced and cultivated greenery is not a part of a park's "wildlife" (though it co-creates its environment). However, a planted tree, existing "on its own" gradually enters the structure of the park and functions as part of its natural life. Peacocks kept uncaged at a park or flightless swans do not belong to the latter either (or belong only to a lesserdegree), given that they would not be able to survive without human help. On the other hand, the squirrels, though they may take advantage of being fed by park-goers, are a part of the wildlife as they are capable of living independently. 


\section{Example from a centrally located urban park}

City parks have generally been infrequently studied in terms of their natural life; in most cases, inventories of their flora were made (tree stands in particular) for gardening purposes. Park wildlife is known chiefly from studies of birds or, to a lesser extent, investigations into "natural" plant life. Other components of the flora (e.g., fungi and mosses) and fauna (Luniak 1983; Sikorski 2013; Zimny 2005) are seldom investigated.

The first comprehensive description of natural life in an urban park in Poland was obtained thanks to studies conducted in 2014-2015 in Warsaw, as part of the project entitled Przyroda Parku Skaryszewskiego (Nature of the Skaryszewski Park) (Luniak 2014 and 2016; Luniak and Romanowski 2016) in which some 40 scientists were involved on a voluntary basis. The area is an example of large (50 ha), frequently visited (ca. 20,000 people during the May weekend, including 600 visitors with dogs) park in the middle of the city, offering various recreational opportunities. Its environmental conditions - that is, old tree stand, bodies of water, fertile soil-as well as manner in which it is managed are beneficial to wildlife. Investigations carried out in the project spanned the sociological background and inanimate natural circumstances, such as local climate, hydro-geological conditions, water and soil quality, penetration of urban noise, as well as-quite extensively-its animate nature.

It was established that Park Skaryszewski provides habitat to approximately 1,00o species of wildlife in the three groups of multicellular living organisms: fungi (including lichens), plants, and animals. The figure does not reflect the actual number of species, because the field research lasted a relatively short time (1-2 seasons) and thus did not encompass many species-abundant groups of invertebrates, such as arachnids, insects and other arthropods, or nematodes. On the other hand, researchers identified several dozens of exotic trees and shrubs which had been planted there; these are not characterized by wildlife provenance but with time have been assimilated into the local ecosystem. It may therefore be assumed that the biodiversity of the park, as far as the abundance of species and their varieties is concerned, considerably exceeds the 1,0oo figure and represents at least 10 (or in excess thereof) percent of the wildlife species composition in the entire city of Warsaw (Luniak 2008).

The level of biodiversity in Skaryszewski Park is indicated the number of species or larger taxonomic groups (taxons) observed in the course of the study (Luniak 2016, Luniak and Romanowski 2016):

- macrofungi-over 130 species, soil microfungi-well over 77 species, lichens -45 species (+ 4 species of lichenized fungi);

- land flora-26 moss species, "wild" herbaceous plants-94 species, and 162 (in 1996) species and varieties of shrubs and trees; 
- aquatic flora comprises at least 40 species and groups of vascular plants and algae;

- aquatic invertebrates-at least 75 species and larger taxonomic groups, including 15 species of snails, and 6 species (each) of bivalves and leeches;

- soil fauna-only three of its numerous taxonomic groups were studied; researchers identified over 20 species of saprophytes, whose number ranged depending on the environment from 13,000 to 45,000 specimens per $\mathrm{m}^{2}$, springtails-31 (11,000$28,000 / \mathrm{m}^{2}$ ), and earthworms -5 species (on average ca. 150 specimens $/ \mathrm{m}^{2}$ );

- land invertebrates, studied considerably below their full range, with snails-15 species, spiders - 43, dragonflies-23, ladybirds-26, diurnal butterflies-24, ants-11, bumblebees and cuckoo bumblebees- 7 , and in all likelihood several dozen species of wild bees.

- vertebrates: fish $-12-16$ species, amphibians -4 species and 1 hybrid form, reptiles -1 species, birds -54 regularly encountered species (including 37 breeding species, amounting to ca. 300 pairs), mammals - ca. 20 species (including 5 or more species of bats).

The particular value of wildlife in the park lies in the presence of rare and protected species of flora and fauna, with over 60 species from national lists of protected species and a similar figure of species from national and global lists of threatened species, not to mention many rarely encountered in the city and the region. For instance, among macrofungi there were 2 nationally protected species and 19 from the national and international Red List. As for soil microfungi, one species had not been previously reported in Poland, and another had been encountered only once before. Also, researchers determined the presence of 3 species of lichenthatare seldom found in Warsaw. As for herbaceous plants, the park boasts a wealth of meadow (48 species) and forest ( 55 species) communities. Aquatic invertebrates include three protected species of bivalves and one protected snail species. In the category of land fauna, 8 of the identified spider species had not been hitherto reported in Warsaw; 6 of the discovered snail species are enumerated in the world Red List, one species of dragonfly is mentioned in the national and European lists of protected species, and there were 4 species of ladybirds which are considered rare in Poland. The assortment of birds includes 50 species from the national list of protected species and 5 species from Annex 1 to the EU Birds Directive. The breeding presence of two Polish species of nightingales (thrush and common nightingale) is a particular rarity and attraction as far as the city of Warsaw is concerned; it is also the only park in the city center area where they can be found.

Detailed findings from the above studies were presented in the monograph by Jerzy Romanowski (2016). 


\section{Why wildlife should be sustained}

Protection/promotion of wildlife in city parks is substantiated with the following arguments:

- the humanitarian argument (universal human aspect) - counteracting the crisis of biodiversity, which represents a global challenge to contemporary civilization. It is our (personal and community-wide) moral obligation (also towards future generations), expressed in laws and regulations, be it local, national, orinternational. Nature is the foundation of humanity's existence and our partner on Earth, which is why we should respect and foster it in our surroundings. Urban greenery creates a singular opportunity for promoting wildlife, as it is not subject to any productivity regime (associated with agriculture, forestry, or game hunting), which means that it enjoys greater "liberty." The argument can be supported with the example of Skaryszewski Park, a site of rich biodiversity and a sanctuary for rare and protected species.

- the ecological argumentrelates again (see above) to the conservation of biodiversity and sustenance of abundant wildlife, though it is manifested in practical care for the quality of the environment in the city where one lives. Among other things, this involves improvement of local climate, restoration of proper oxygen and $\mathrm{CO}_{2}$ balance (a negative one in urban areas), absorption of chemical contamination by plants, as well as reduction of pollution with particulate matter (a particularly topical issue) and noise. In terms of natural life, more abundant and more valuable urban greenery (old tree stands) performs this ecological role much better than other solutions. For an eloquent example, one could cite an excerpt from an interview with the eminent dendrologist Professor Jacek Borowski (Warsaw University of Life Science): “a 6o-year-old pine produces an annual volume of oxygen that is consumed by three persons. A healthy, 10-metre high broad leaf produces $120 \mathrm{~kg}$ of oxygen, while average human requirement is $176 \mathrm{~kg}$. This means that two small trees supply the needs of any single person" (Aksamit 2017).

- the social argument consists in the growing demand among city inhabitants for recreation in friendly contact with nature. This regularity is observed in countries with advanced standards of living (Jakubowski 2017). Another trend noted there (as well as in Poland) is increased social involvement in protection of nature within cities. In Warsaw, this is reflected both in surveys (Cieszewska, Lachowska, Szumacher 2016) and widespread public protests against degradation of nature in parks-that is, the recent response to the manner in which the Krasiński Gardens were to be revitalized (in 2013). Care for the natural assets of urban parks is tantamount to meeting social needs in that respect. A lawn in the form of a "flower meadow," with butterflies and bees, finds increasing approval compared with a meticulously tended "carpet," while a run-down oak with 
multiple hollows that has been saved from felling is preferred to a row of newly planted Japanese cherry trees, which will never reach even a half of the oak's age nor its monumental magnificence.

- the economic argument-a nature- (wildlife-) friendly park is cheaper to maintain. More numerous interventions which "oppose" natural structures and processes by, for instance, eliminating natural plant life, felling old trees, intensive lawn maintenance, raking litter, shoring and paving banks of bodies of water with concrete all result in increased costs and lower durability of adopted solutions.

\section{Major recommendations}

Provided below there are a number of briefly formulated recommendations which might serve to protect/shape living nature (wildlife) in city parks. Their practical implementation should obviously take the requirement of recreational and historical (if applicable) function of a park into account.

1. At the stage of park design, areas intended for greenery should be the most valuable in environmental terms and ensure ecological continuity with neighboring green areas; designs should be consulted with experts in the field of natural life, whose specialties are broader than the knowledge of landscape architects and gardening practitioners.

2. While arranging or revitalizing a park, one should minimize the destruction of existing natural assets, conserve - as much as possible - the continuity of wildlife, soil, and native plants in a given area. Old trees are a particularly important element of that continuity. One should ensure richness of vegetation, with a diverse species composition adjusted to the habitat and structure (in terms of age and layers). It would be beneficial to shield the area from the neighborhood's urban traffic with a belt of high and dense shrubs (hedges). Furthermore, one should also foster the presence and growth of indigenous plants, adapted to local natural conditions, as they are cheaper to maintain and serve the fauna better. Zones of utilization should be defined with some forethought; for instance, areas where crowds and noise are likely to be present should be situated on the edges of the park. Also, special zones (sanctuaries) should be established to mitigate the conflict between intense use of the park and its natural function as well as to enable nature-related educational activities. Bodies of water and watercourses enrich the natural life of a park, and therefore they should be surrounded with natural littoral flora and have easy access to and egress from water for land animals. Moreover, one should provide breeding or nesting boxes for birds, bats, and squirrels, watering sites/drinkers, shelters for hedgehogs, insect hotels, rafts/landings for aquatic fowl, as well as arrange and protect sites 
within bodies of water where fish and amphibians may proliferate. Threats to fauna should be minimized: birds collide with transparent or mirrorlike glass surfaces. Unsecured lighting (dissipated to the sides) wreaks havoc on populations of nocturnal insects, causing thermal shock or exhaustion. Pest control measures should not be used with respect to moles, as they are an important part of wildlife and contribute to soil fertility. The structure of the fences should allow amphibians and small mammals (hedgehogs) to pass through without leading them into routes of urban traffic. Zones that are accessible/inaccessible to dogs have to be demarcated as well.

3. Finally, in the course of maintenance and utilization, one should minimize practices which deplete vegetation (e.g., adjusting mowing frequency and height), removal of the remains of natural plant life-fallen leaves and litter, as well as withered branches and tree trunks. Chemical agents should be avoided when fertilizing or protecting plants and controlling oppressive insects (e.g., mosquitoes); park alleys should not be salted in winter nor rat poison laid out. The environment of parks, usually over-dry, should be well irrigated. While performing gardening procedures, care should be taken not to harm the fauna-that is, avoid damaging or destroying bird nests containing eggs or young specimens, killing invertebratesor amphibians while mowing, or contaminating the area with chemical agents. Furthermore, discarded or submerged fishing lines (as well as cords, cables, and soft nets) in which animals become tangled (as they use them to line their nests or burrows) should be removed, while animals should not be disturbed in their breeding sites and sanctuaries. Trees and shrubs should not be pruned or cut during birds' breeding season (April-August). Stoppages in water supply to bodies of water and watercourses should be minimalized, as such shortages havean adverse effect on their biocœnoses; in particular, ponds must not be cleaned while amphibians are breeding. Unreasonable feeding of animals-birds and fish-should be minimized as well, so as not to draw large numbers of aquatic fowl, corvids, city pigeons, or rats, not to mention general pollution, especially for bodies of water in the park. It is crucial, however, to provide a watering (and bathing) site for the animals with easy and safe access that accommodates various animal groups (insects, birds, small mammals, and amphibians). Knowledge concerning natural life should be propagated too in order to acquaint visitors coming to the park (and staff performing variousworks there) with its nature, to establish friendly attitudes, and to facilitate its protection. Lastly, the park should be kept free of cats. 


\section{Maciej Luniak}

\section{References:}

Aksamit, Bożena. 2017. "Były sobie drzewa" ["There Were Once Trees"]. Gazeta Wyborcza —Duży, March 27.

Cieszewska, Agata, Małgorzata Lachowska, andlwona Szumacher. 2016. "Użytkownicy Parku Skaryszewskiego w Warszawie w latach 2009 — 2015" ["Users of Park Skaryszewski in Warsaw in 2009—2015"]. In Park Skaryszewski w Warszawie - przyroda i użytkowanie [Park Skaryszewski in Warsaw-nature and usage], edited by Jerzy Romanowski, 37-47. Warsaw: UKSW.

Jakubowski, Kacper. 2017. "Współczesne tendencje w projektowaniu przestrzeni dla edukacji ekologicznej w miastach" ["Contemporary Trends in Designing Spaces for Ecological Education in Cities"]. Dzikie Życie 5 (275): 19-23.

Luniak, Maciej. 1983. "The Avifauna of Urban Green Areas in Poland and Possibilities of Managing It." Acta Ornithologica 19: 3-61.

Luniak, Maciej. 2008. "Fauna of the Big City_Estimating Species Richness and Abundance in Warsaw, Poland." In Urban ecology - an international perspective on the interaction between humans and nature, 349-54. New York: Springer.

Luniak, Maciej. 2014. Przyroda Parku Skaryszewskiego-raportz realizacji Projektu w 2014 [Nature in Park Skaryszewski_report from the project in 2014]. www.miastoiptaki.pl/raport_ppsk/.

Luniak, Maciej. 2016. "Projekt "Przyroda Parku Skaryszewskiego" w latach 2014-2015" ["Project "Nature in Park Skaryszewski" in 2014-2015"]. In Park Skaryszewski w Warszawie-przyroda i użytkowanie [Park Skaryszewski in Warsaw — Nature and Usage], edited by Jerzy Romanowski, 9-15. Warsaw: UKSW.

Luniak, Maciej and Jerzy Romanowski. 2016. "Projekt "Przyroda Parku Skaryszewskiego"—-podsumowanie naukowych wyników badań w latach 2014-2015" [Project Nature in Park Skaryszewski - asummary of research results in 2014-2015]. In Park Skaryszewski w Warszawie — przyroda i użytkowanie [Park Skaryszewski in Warsaw — Nature and Usage], edited by Jerzy Romanowski, 243-50. Warsaw: UKSW.

Romanowski, Jerzy. 2016. Park Skaryszewski w Warszawie-przyroda i użytkowanie [Park Skaryszewski in Warsaw-Nature and Usage]. Warsaw: UKSW.

Sikorski, Piotr. 2013. Wpływ naturyzacji parku miejskiego na różnorodność florystyczną runa i trawników parkowych [The Effect of Naturalizing Urban Parks on Floral Diversity of Undergrowth and Lawns in Parks]. Warsaw: Wieś Jutra.

Zimny, Henryk. 2005. Ekologia miasta [Urban ecology]. Stare Babice: Agencja Reklamowo-Wydawnicza A. Grzegorczyk. 